\title{
Prototype Sistem Pengelolaan Karyawan Kontrak Berbasis Progressive Web Application Pada Perusahaan Outsourcing
}

\author{
Novi Cholisoh*1 \\ PO Abas Sunarya ${ }^{2}$ \\ Filza Harry Prayogo ${ }^{3}$ \\ 1,2,3 Program Studi Teknik Informatika Fakultas Sains dan Teknologi Universitas Raharja \\ Email : *11novi@ raharja.info, ${ }^{2}$ abas.sunarya@ raharja.info, ${ }^{3}$ filza@ raharja.info
}

\begin{abstract}
Abstraksi
Setelah berdiri selama kurang lebih 20 tahun lamanya, PT. Aplus Pacific terus mengalami perkembangan yang cukup pesat. Salah satunya yaitu meningkatnya jumlah karyawan baik dari sisi personalia karyawan PT Aplus Pacific maupun hasil kerjasama dengan perusahaan lain yang bergerak dibidang outsourcing ( Alih Daya ).Hingga saat ini PT. Aplus Pacific telah memiliki karyawan lebih dari 500 karyawan yang tersebar di beberapa cabang. Sehingga membuat sebuah kompleksitas dalam pengelolaan personalia khususnya data terkait karyawan kontrak dari outsourcing. Berdasarkan fakta tersebut, maka peneliti melihat potensi permasalahan yang akan timbul, yaitu menurunnya pelayanan dari Departemen HRD terhadap karyawan kontrak dari outsourcing seperti yang berkaitan dengan masa kontrak, informasi pendapatan, surat izin serta informasi-informasi penting lainnya. Karena saat ini tim dari Departemen HRD masih melayani karyawan kontrak dari outsourcing dengan metode penginputan secara manual. Hal tersebut memiliki beberapa kekurangan yang dapat menghambat proses penyelesaian masalah, seperti sulitnya mengingat waktu masa habis kontrak seorang karyawan, informasi gaji yang terlambat, dan pengurusan surat izin yang cukup sulit. Maka dari itu tujuan utama penelitian ini adalah merancang suatu sistem yang dapat mengakomodir banyaknya kebutuhan dan keluhan karyawan kontrak dari outsourcing di PT. Aplus Pacific dengan cepat dan terdokumentasi dalam history sebagai arsip dan acuan oleh tim Departemen HRD untuk menyelesaikan problem dengan lebih cepat. Dan dengan adanya sistem tersebut, Departemen HRD bisa melakukan pembenahan dan pengembangan guna meningkatkan kepuasan karyawan kontrak kerja outsourcing terhadap pelayanan Departemen HRD. Dengan demikian untuk mewujudkan tujuan diatas penelitian ini berencana merancang sistem aplikasi berbasis Progressive Web Apps ( PWA) dan menggunakan bahasa pemrograman Javascript dengan framework Node.js dan menggunakan basis data MongoDB.
\end{abstract}

Kata kunci: Outsourcing, Kontrak Karyawan, Progressive Web Apps, Node.js

\section{Abstract}

After standing for approximately 20 years, PT. Aplus Pacific continues to experience rapid development. One of them is an increase in the number of employees both in terms of the personnel of PT Aplus Pacific employees and the results of cooperation with other companies engaged in outsourcing (Transfer of Power). Until now PT. Aplus Pacific has more than 500 employees spread across several branches. So that makes a complexity in managing personnel, especially data related to contract employees from outsourcing. Based on these facts, the researcher sees the potential problems that will arise, namely the decline in services from the HRD Department to contract employees from outsourcing such as those related to the contract period, income information, permits and other important information. Because right now the team from the HRD Department is still serving contract employees from outsourcing with the manual input method. This has several drawbacks that can hinder the process of problem 
solving, such as the difficulty of remembering the time of an employee's contract expiration, late salary information, and the management of permits which are quite difficult. Therefore the main purpose of this study is to design a system that can accommodate the many needs and complaints of contract employees from outsourcing at PT. Aplus Pacific is quickly and documented in history as an archive and reference by the HRD Department team to solve problems faster. And with this system, the HRD Department can make improvements and development in order to increase the satisfaction of outsourcing work contract employees with HRD Department services. Thus to realize the above objectives this research plans to design an application system based on Progressive Web Apps ( PWA) and use the Javascript programming language with the Node.js framework and use a MySQL database.

Keywords: Outsourcing, Support, Progressive Web Apps, Node.js

\section{PENDAHULUAN}

Perkembangan yang pesat di bidang teknologi komputer, elektronik, telekomunikasi maupun mekanik telah menghasilkan berbagai aplikasi canggih dan cerdas yang merubah kehidupan manusia pada saat ini dan mendatang.Seiring berjalannya perkembangan zaman, peran teknologi informasi dan komunikasi sangat berdampak positif dalam meningkatkan kualitas hidup manusia.Salah satu implementasi dari peran teknologi informasi yaitu penggunaan sistem informasi untuk membantu kinerja organisasi suatu perusahaan.Dengan didukung oleh kecanggihan teknologi informasi, telah memungkinkan pengembangan sistem informasi yang semakin handal khususnya penanganan dalam manajemen sistem kontrak karyawan.

Beberapa perusahaan outsourcing pasti memiliki karyawan yang berstatus kontrak, sebagai salah satu contoh untuk dapat melakukan riset terkait objek penelitian, penulis mengambil tempat pada perusahaan yang bergerak dalam bidang outsourcing, yang merupakan perusahaan yang bergerak di bidang industri yaitu memproduksi bahan bangunan dan sistem konstruksi.

Dalam melakukan penerimaan karyawan baru dan pengelolaan karyawan kontrak saat ini masih memiliki kekurangan.Terdapat beberapa permasalahan pada sistem yang diterapkan yaitu masih manual, karena penginputan data karyawan baru masih print out form registrasi dan melakukan pengambilan data dengan mengisi form tersebut secara manual. Hal ini sangat merepotkan dan membutuhkan biaya cukup besar, sementara itu setelah proses pendataan selesai dilaksanakan maka form registrasi karyawan yang telah direkap hanya menjadi arsip saja. Tentu hal ini menyebabkan pemborosan. Selain itu beberapa permasalahan lainnya, tidak adanya pengingat untuk setiap karyawan yang kontrak kerjanya telah habis sehingga banyak karyawan yang melewati akhir masa kontrak kerjanya namun tetap bekerja sehingga tidak sesuai dengan perjanjian pada MoU antara Karyawan dengan perusahaan outsourcing.

Karyawan merupakan subjek penting dalam sebuah organisasi perusahaan.Manusia memiliki kemampuan untuk menggerakkan semua sumber daya organisasi yang ada. Tanpa adanya karyawan yang profesional, organisasi perusahaan akan sulit berkembang karena kekuatan setiap perusahaan terletak pada karyawan yang mengelola dan penanganannya.

Bila merujuk pada Undang Undang No. 13 Tahun 2003 tentang ketenagakerjaan, Outsourcing (Alih Daya) dikenal sebagai penyediaan jasa tenaga kerja seperti yang diatur pada pasal 64, 65 dan 66. Dalam dunia Psikologi Industri, tercatat karyawan outsourcing adalah karyawan kontrak yang dipasok dari sebuah perusahaan penyedia jasa tenaga outsourcing

Aplikasi berbasis Progressive Web Apps (PWA) adalah sebuah istilah untuk aplikasi berbasis web yang menggunakan teknologi web paling mutakhir. PWA sebenarnya hanyalah aplikasi berbasis web biasa, tapi memanfaatkan fitur prambanan yang modern agar tampil seolah-olah merupakan aplikasi asli ( native) [1][8]. PWA digambarkan sebagai kumpulan dari teknologi, konsep desain dan RESTful API ( Application Programming Interface) yang bekerja 
secara bersama untuk memberikan sentuhan aplikasi pada sebuah mobile web [2][12]. Hal ini termasuk berbagai rekomendasi yang tidak spesifik pada desain aplikasi web untuk perangkat mobile, seperti preferensi HTTPS melalui HTTP dan desain yang responsive. Hal ini juga akan membawa kebutuhan pada API baru untuk peningkatan kualitas pengguna, seperti Web App Manifest, Service Workers ataupun Payment Request API [3][4].

Keuntungan dari PWA ini adalah dapat memuat konten seketika bahkan dalam kondisi jaringan yang tidak baik.Ketika digunakan dari layar awal pengguna, maka service worker diaktifkan pada PWA untuk dimuat seketika.Salah satu Konsep yang dibangun oleh PWA adalah Service Worker.Service worker adalah script yang berjalan di belakang browser pengguna. Service worker tidak membutuhkan sebuah halaman maupun interaksi dari pengguna untuk menjalankan tugasnya, dengan begitu service worker akan terus berjalan walaupun halaman web tidak terbuka [5][12].

Untuk dapat menyelesaikan permasalahan diatas, perlu dibuat suatu model sistem yang dapat mendukung pengoptimalan kinerja HRD perusahaan outsourcing terhadap karyawan kontrak. Hal dapat diselesaikan menggunakan berbagai metode penelitian diantaranya observasi, wawancara, studi pustaka. Dan untuk menggambarkan suatu sistem penulis menggunakan desain UML ( Unified Modelling Language) yang akan menggambarkan use case diagram, activity diagram, sequence diagram dan class diagram [6][7][9]. Sebagai gambaran dari hasil analisis menggunakan PIECES.Untuk memberikan model gambaran sistem penulis juga menggunakan progressive web application sebagai media implementasi.

\section{METODE PENELITIAN}

Metode penelitian merupakan suatu tata cara atau kegiatan pelaksanaan penelitian rangka untuk mengumpulkan informasi atau data serta melakukan investigasi terhadap data yang telah didapatkan tersebut. yang didasari oleh asumsi-asumsi dasar, pandangan-pandangan filosofis dan ideologis, pertanyaan dan isu-isu yang dihadapi [10][11]. Suatu penelitian mempunyai rancangan penelitian tertentu. Rancangan ini menggambarkan prosedur atau langkah-langkah yang harus ditempuh, waktu penelitian, sumber data dan kondisi arti untuk apa data dikumpulkan dan dengan cara bagaimana data tersebut dihimpun dan diolah untuk dianalisa dalam pembuatan laporan [13].

\subsection{Metode Observasi (Observasi Research)}

Pada tahapan ini penulis melakukan pengamatan langsung dari objek penelitian terutama pada bagian HRD, untuk mendapatkan data dan informasi yang akurat dan lengkap dari berbagai pihak yang terkait dan berhubungan dengan tema penelitian yang berhasil penulis rumuskan.

\section{a. Metode Wawancara (Interview Research)}

Penulis melakukan wawancara pada bagian HRD yang melakukan pengelolaan data kontrak kerja karyawan, penulis mendapatkan informasi berkaitan dengan penelitian penulis.

\section{b. $\quad$ Metode Studi Pustaka (Studi Literature)}

Selain melakukan observasi penulis juga melakukan data dengan cara studi pustaka dalam metode ini penulis berusaha untuk melengkapi data-data yang diperoleh dengan membaca dan mempelajari dari buku-buku dan data-data yang relevan. Buku dan data tersebut digunakan penulis untuk membantu penganalisaan dan perancangan yang dilakukan.

\subsection{Metode Analisis Data}

Pada penelitian ini, metode analisis dilakukan dengan langkah-langkah melakukan pengamatan dan analisa terhadap sistem yang berjalan saat ini, serta menentukan UML (Unified Modeling Language) yang meliputi use case diagram, activity diagram, sequence diagram. 


\section{PEMBAHASAN}

Untuk dapat menggambarkan prosedur secara keseluruhan diperlukan beberapa tahapan analisa sebagai bentuk pengumpulan informasi guna mendapatkan model yang sesuai dengan kebutuhan dan mampu memberikan solusi dengan cepat secara efektif dan efisien, mulai dari tahapan pengumpulan informasi dan kebutuhan, analisa dokumen, rancangan hubungan antar dokumen sampai dengan merancang model diagram database dan model rancangan sistem. Beberapa tahapan yang dimaksud sampai dengan model rancangan yang diciptakan dapat dilihat pada gambar $1,2,3,4,5$.

\subsection{Use Case Diagram Prosedur Berjalan}

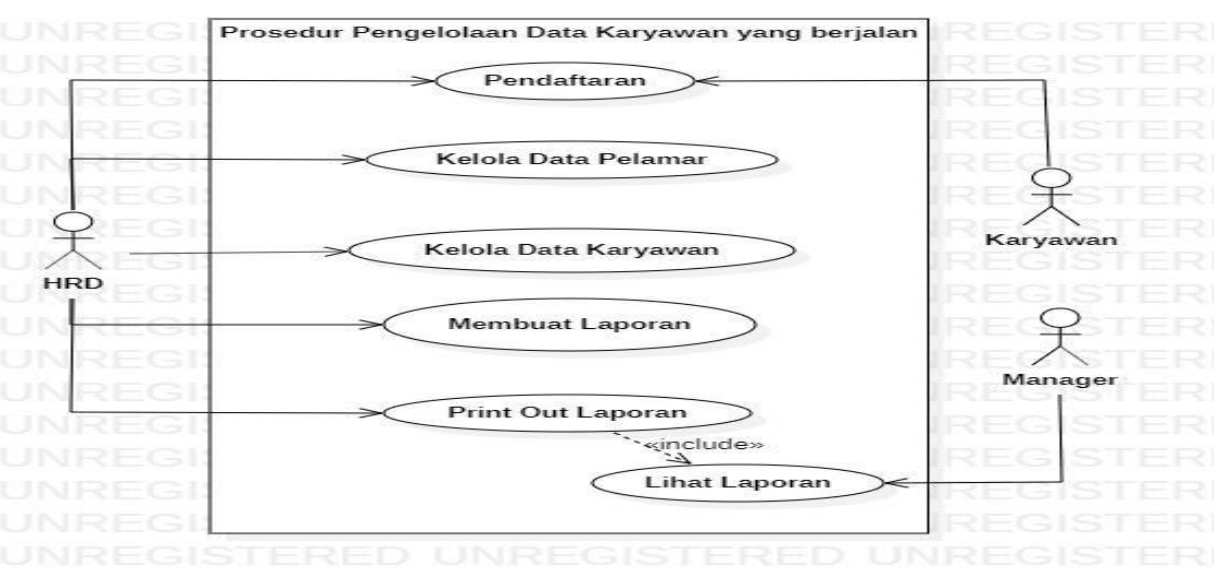

Gambar 1. Use Case Diagram Berjalan

Berdasarkan gambar use case Diagram (gambar 1) yang berjalan saat ini sistem yang mencakup seluruh kegiatan pada sistem kontrak kerja karyawan pada perusahaan outsourcing. Terdapat 3 (tiga) Aktor yang melakukan kegiatan yaitu HRD, Karyawan dan Manajer yang diawali dengan HRD membuka pendaftaran (lowongan kerja) untuk calon karyawan / pelamar, kemudian jika pelamar berhasil menjadi karyawan maka akan mendapat kontrak kerja yang memiliki durasi waktu tertentu. Setelah itu seluruh data-data karyawan akandilaporkan kepada Manajer Perusahaan.

Terdapat juga 6 (enam) use case yang merupakan proses yang terjadi pada sistem berjalan yaitu membuka pendaftaran, mengelola data pelamar, mengelola data karyawan, membuat data-data tersebut menjadi bentuk laporan, setelah itu melakukan print out laporan dan yang terakhir adalah melihat laporan.

\subsection{Activity Diagram Prosedur Berjalan}




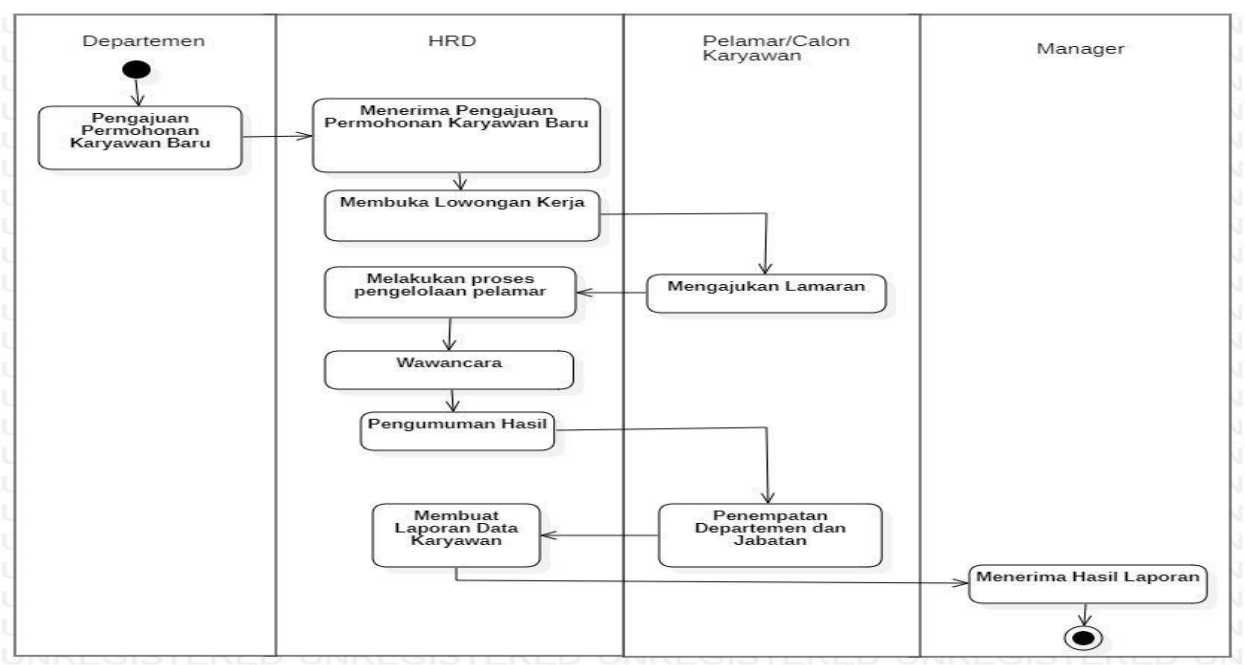

Berdasarkan gambar activity diagram (gambar 2) yang berjalan saat ini sistem mencakup seluruh kegiatan sistem kontrak kerja karyawan kontrak pada perusahaan outsourcing. Sistem ini melibatkan 4 (empat) Actor yaitu, Departemen, HRD, Karyawan, Manager. Diawali dengan Departemen mengajukan permohonan karyawan baru kepada HRD, lalu HRD menerima dan membuat lowongan kerja, jika ada pelamar yang mendaftar, maka HRD akan mengelola data pelamar tersebut untuk di tes sehingga ada pengelolaan data calon karyawan.Jika pelamar lolos, maka HRD akan melakukan interview dan mengumumkan hasil Interview. Jika pelamar lolos maka pelamar akan menjadi calon karyawan dan melakukan penempatan kerja sesuai Departemen yang mengajukan. Setelah itu HRD kemudian mengubah status calon karyawan menjadi karyawan kontrak dengan beberapa ketentuan dalam bentuk laporan yang kemudian laporan tersebut diberikan kepada Manajer sebagai bentuk data laporan kontrak karyawan.

\subsection{Sequence Diagram Prosedur Berjalan}

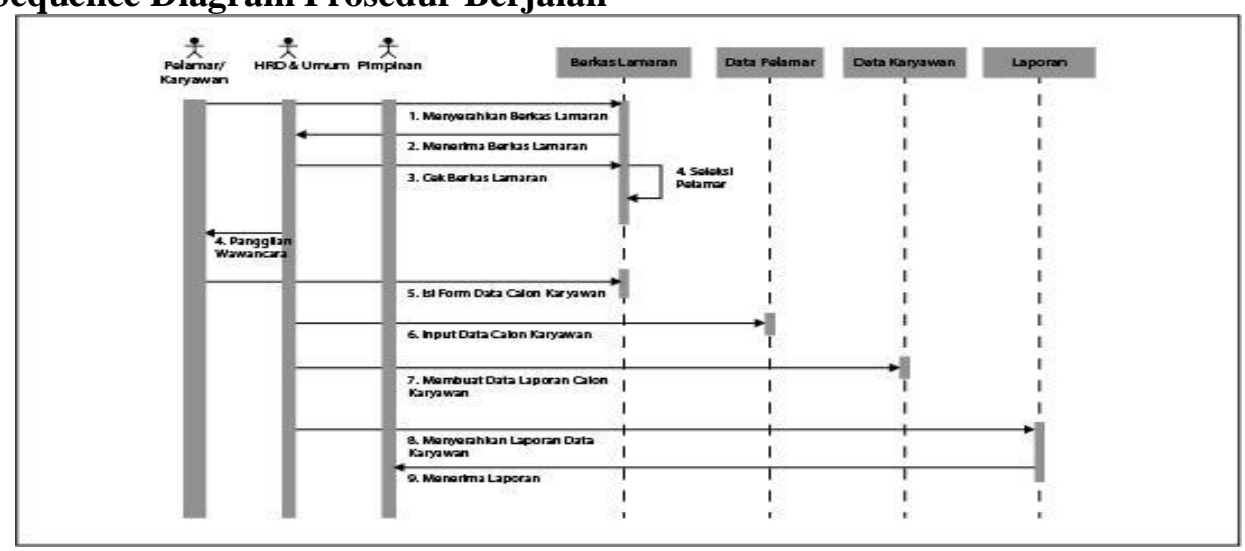

Gambar 3. Sequence Diagram

Berdasarkan gambar sequence diagram (gambar 3) yang berjalan saat ini terlihat 3 aktor yang melakukan kegiatan yaitu HRD, Karyawan, dan Manajer yang akan menyelesaikan 9 message yaitu, menyerahkan berkas lamaran, menerima berkas lamaran, cek berkas lamaran, seleksi pelamar, panggilan wawancara, isi form data calon karyawan, input data calon karyawan, membuat data laporan calon karyawan dan yang terakhir yaitu menerima laporan.

Rancangan diatas (gambar 1, 2, 3) merupakan gambaran prosedur yang berjalan dimana pada tahapan ini melibatkan beberapa dokumen seperti membuat form pengajuan karyawan, form pendaftaran calon karyawan, form uji tertulis, form input data karyawan, dan laporan data 
karyawan. Dimana membuat form pengajuan diisi oleh bagian departemen yang berfungsi untuk mengkomunikasikan kepada HRD bahwa di bagian departemen tersebut sedang membutuhkan karyawan baru. Form uji tertulis berfungsi untuk melihat kemampuan pelamar atau calon karyawan. Form input data karyawan berfungsi untuk mendata karyawan baik yang sudah kontrak maupun calon karyawan. Dan laporan digunakan untuk memberikan laporan secara fisik terhadap Manajer perusahaan terkait data kontrak karyawan.

\subsection{Class Diagram}

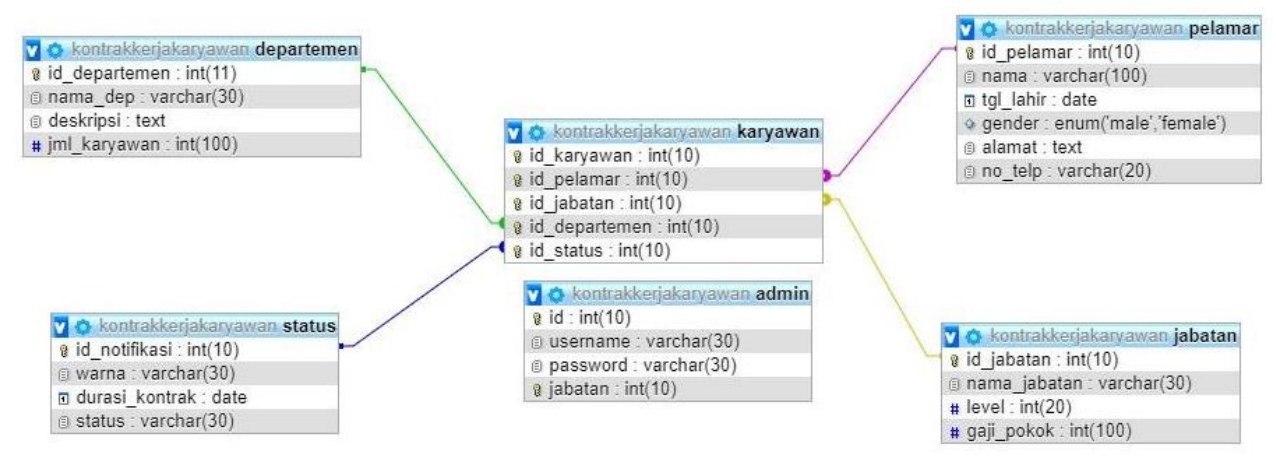

Gambar 4. Class Diagram

Berdasarkan gambar class diagram (gambar 4). Terdapat 5 (lima) kelas yaitu, departemen, karyawan, jabatan, pelamar dan notifikasi yang merupakan tabel master, serta admin sebagai tabel untuk login dan registrasi.

Berdasarkan gambar class diagram (gambar 4) diatas dapat dilihat dengan jelas bahwa tingkat hubungan departemen dan karyawan yaitu one to many (1:M), tingkat hubungan jabatan dan karyawan one to many $(1: \mathrm{M})$, tingkat hubungan pelamar dan karyawan yaitu one to many $(1: \mathrm{M})$, tingkat hubungan status dan karyawan yaitu one to many $(1: \mathrm{M})$, tabel admin tercipta karena adanya fitur login.

\subsection{Use Case Diagram Usulan}

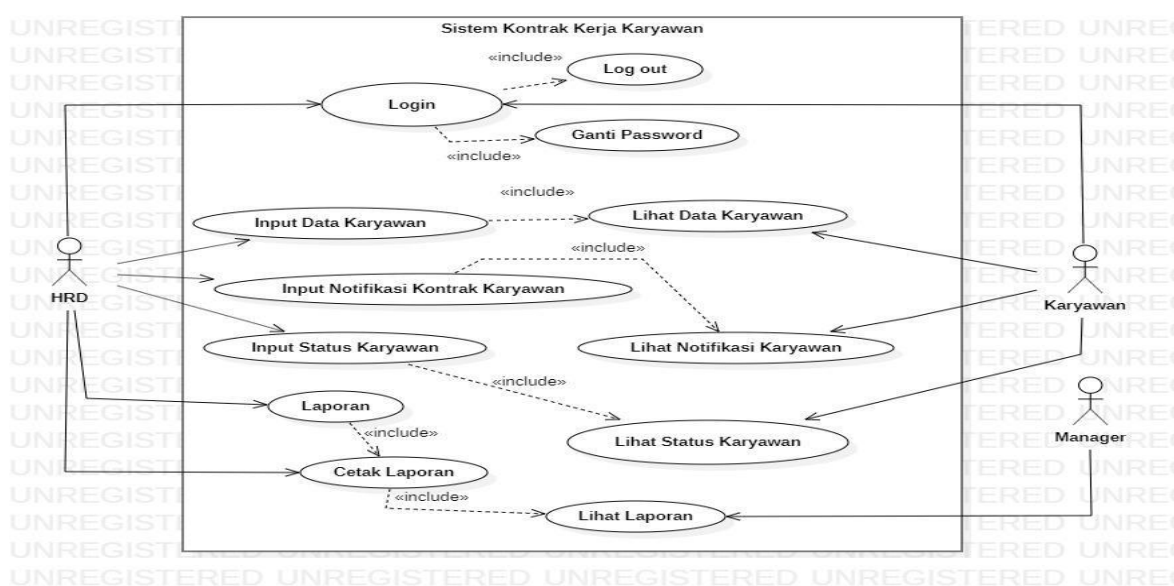

Gambar 5. Use Case Diagram Usulan

Berdasarkan gambar use case diagram usulan (gambar 5) terlihat jelas bahwa terdapat 12 (dua belas) use case yang terdiri login, logout, ganti password, input data karyawan, input 
notifikasi kontrak karyawan, input status karyawan, lihat data karyawan, lihat notifikasi karyawan, lihat status karyawan, dan lihat laporan.

Use diagram sebagai bentuk rancangan sistem yang akan diciptakan (gambar 5 dan 6) merupakan desain model tampilan utama yang berorientasi pada kebutuhan menu pada aplikasi yang disiapkan, selain itu untuk kebutuhan penyimpanan informasi data agar dapat digunakan secara histori juga digambarkan dalam bentuk class diagram (gambar 4) lengkap dengan informasi field dan tipe data sesuai kebutuhan penyimpanan data.

\section{IMPLEMENTASI}

\subsection{Rancangan Basis Data}

Untuk dapat menggambarkan bentuk basis data secara utuh, peneliti menggunakan aplikasi phpmyadmin sebagai bentuk gambaran dasar, dan pada akhirnya bentuk rancangan basis data ini dapat disesuaikan menggunakan apa saja sesuai kebutuhan.

a. Tabel Master: Pelamar

Primary Key : id_pelamar

Foreign Key : : -

Structure Tabel $\quad: \quad\{$ id_pelamar, nama, tgl_lahir, gender, alamat, no_telp $\}$

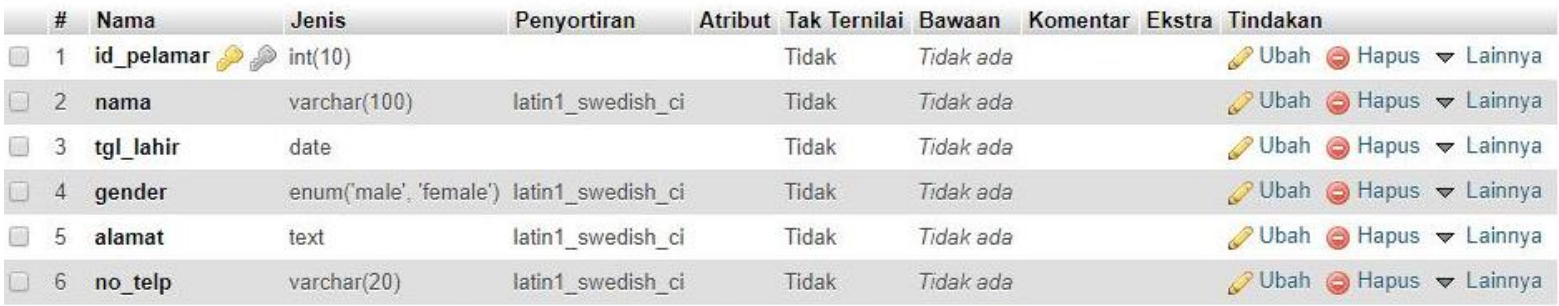

Tabel 1. Tabel Pelamar

b. Tabel Master: Departemen

Primary Key : Kode_Departement

Foreign Key : : -

Structure Tabel : \{id_departemen, nama_dep, deskripsi,jml_karyawan $\}$

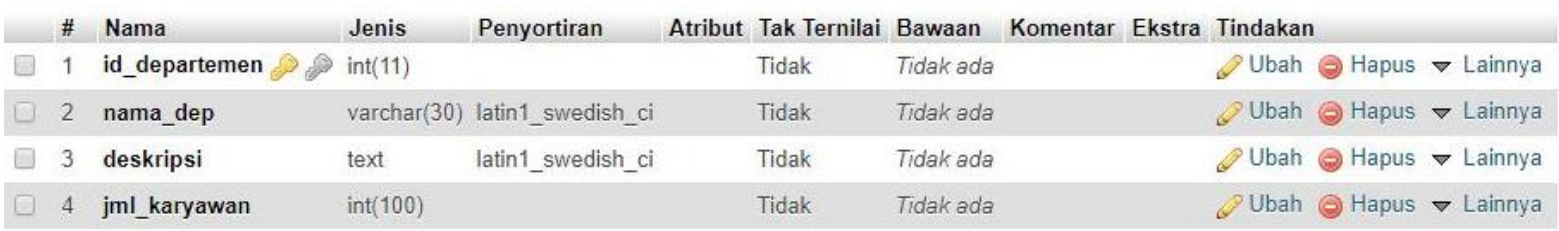

Tabel 2. Tabel Departemen

c. Tabel Master: Jabatan

Primary Key : id_jabatan

Foreign Key

Structure Tabel $\quad: \quad\{$ id_jabatan, nama_jabatan, level, gaji_pokok $\}$

$\begin{array}{llllll}\text { \# Nama } & \text { Jenis } & \text { Penyortiran } & \text { Atribut Tak Ternilai Bawaan Komentar Ekstra Tindakan } \\ 1 & \text { id_jabatan } & \text { int(10) } & \text { Tidak } & \text { Tidak ada } & \text { Ubah } \odot \text { Hapus } \nabla \text { Lainnya } \\ 2 & \text { nama_jabatan } & \operatorname{varchar}(30) \text { latin1_swedish_ci } & \text { Tidak } & \text { Tidak ada } & \text { Ubah } \odot \text { Hapus } \nabla \text { Lainnya } \\ 3 & \text { level } & \operatorname{int}(20) & \text { Tidak } & \text { Tidak ada } & \text { Ubah } \odot \text { Hapus } \nabla \text { Lainnya } \\ 4 & \text { gaji_pokok } & \operatorname{int}(100) & \text { Tidak } & \text { Tidak ada } & \text { Ubah Hapus } \nabla \text { Lainnya }\end{array}$

Tabel 3. Tabel Jabatan 
d. Tabel Master: Karyawan

Primary Key : id_karyawan

Foreign Key : \{ id_pelamar, id_departemen, id_jabatan, id_status \}

Structure Tabel : \{ id_karyawan, id_pelamar, id_departemen, id_jabatan, id_status \}

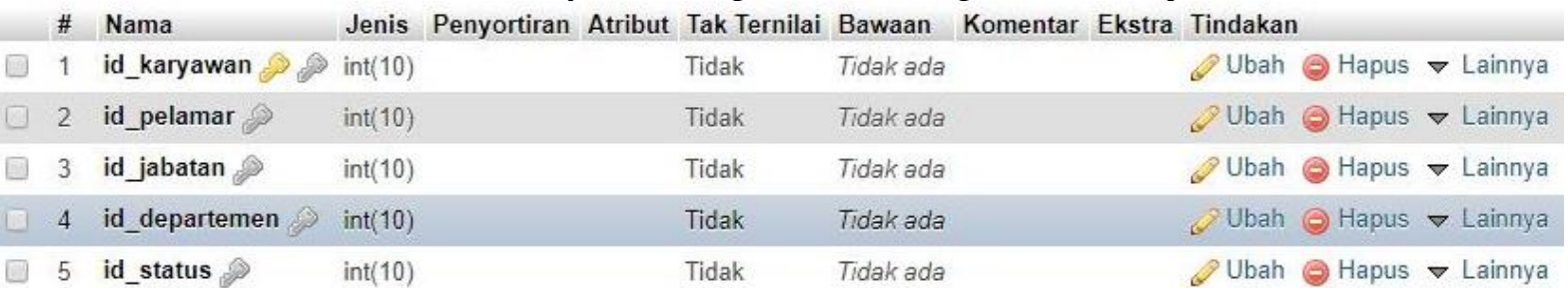

Tabel 4. Tabel Form

e. Tabel Transaksi: Status

Primary Key : id_notifikasi

Foreign Key : -

Structure Tabel : \{id_notifikasi, warna, durasi_kontrak, status $\}$

\begin{tabular}{|c|c|c|c|c|c|c|c|c|c|c|}
\hline & \# & Nama & Jenis & Penyortiran & Atribut & Tak Ternilai & Bawaan & Komentar Ekstra & Tindakan & \\
\hline$\square$ & 1 & id_notifikasi & $\operatorname{int}(10)$ & & & Tidak & Tidak ada & & Ubah $>$ Hapus & $\nabla$ Lainnya \\
\hline$\square$ & 2 & warna & $\operatorname{varchar}(30)$ & latin1_swedish_ci & & Tidak & Tidak ada & & Ubah $\odot$ Hapus & $\nabla$ Lainnya \\
\hline$\square$ & 3 & durasi_kontrak & date & & & Tidak & Tidak ada & & Ubah Hapus & $\nabla$ Lainnya \\
\hline$\square$ & 4 & status & $\operatorname{varchar}(30)$ & latin1_swedish_ci & & Tidak & Tidak ada & & Ubah $\odot$ Hapus & $\nabla$ Lainnya \\
\hline
\end{tabular}

Tabel 5. Tabel Status

\subsection{Grafik Sistem Produksi Obat}

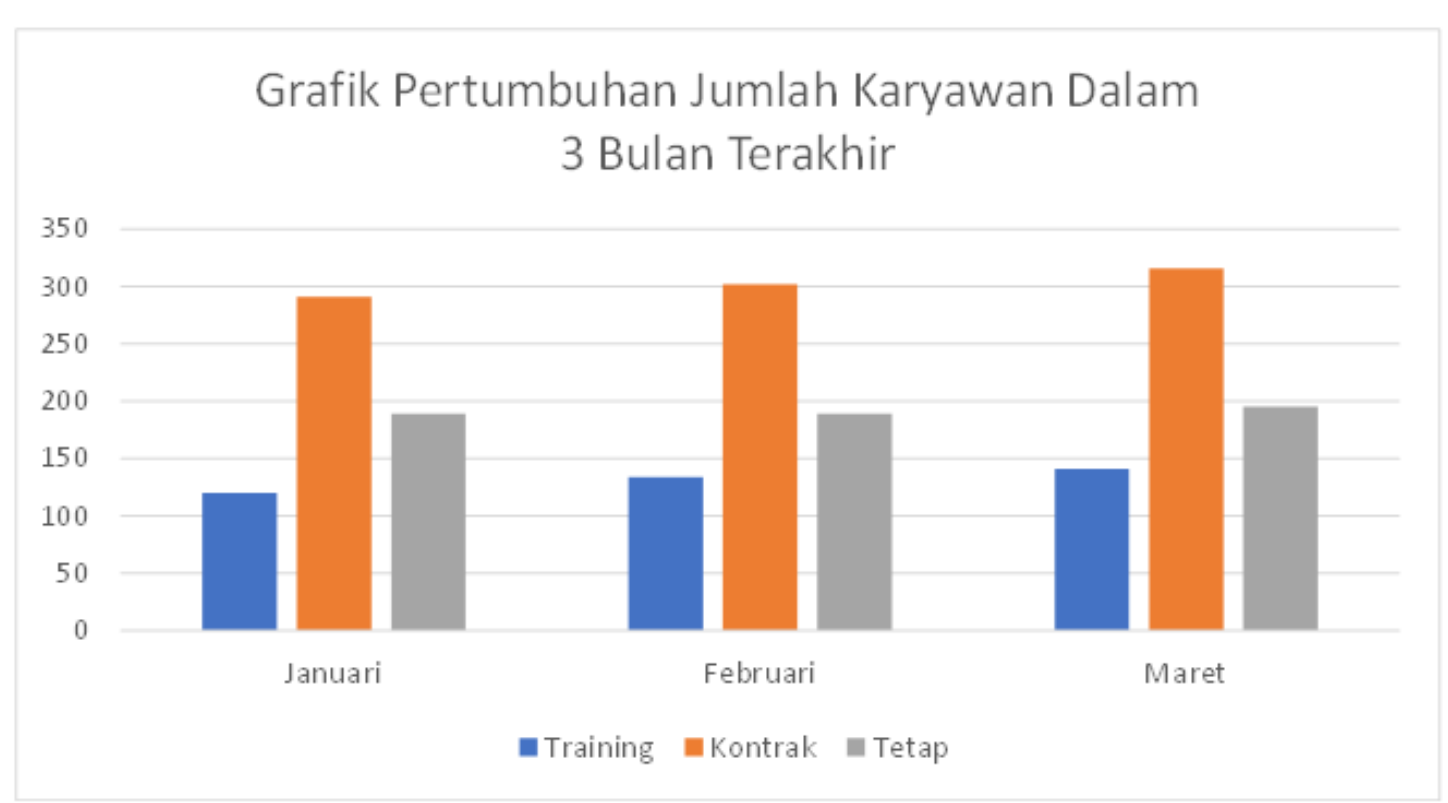

Gambar 6. Grafik Pertumbuhan Jumlah Karyawan Dalam 3 Bulan Terakhir

Grafik diatas (gambar 6) merupakan grafik dari pertumbuhan jumlah karyawan berstatus training, kontrak dan tetap selama 3 bulan terakhir. 


\subsection{Diagram HIPO}

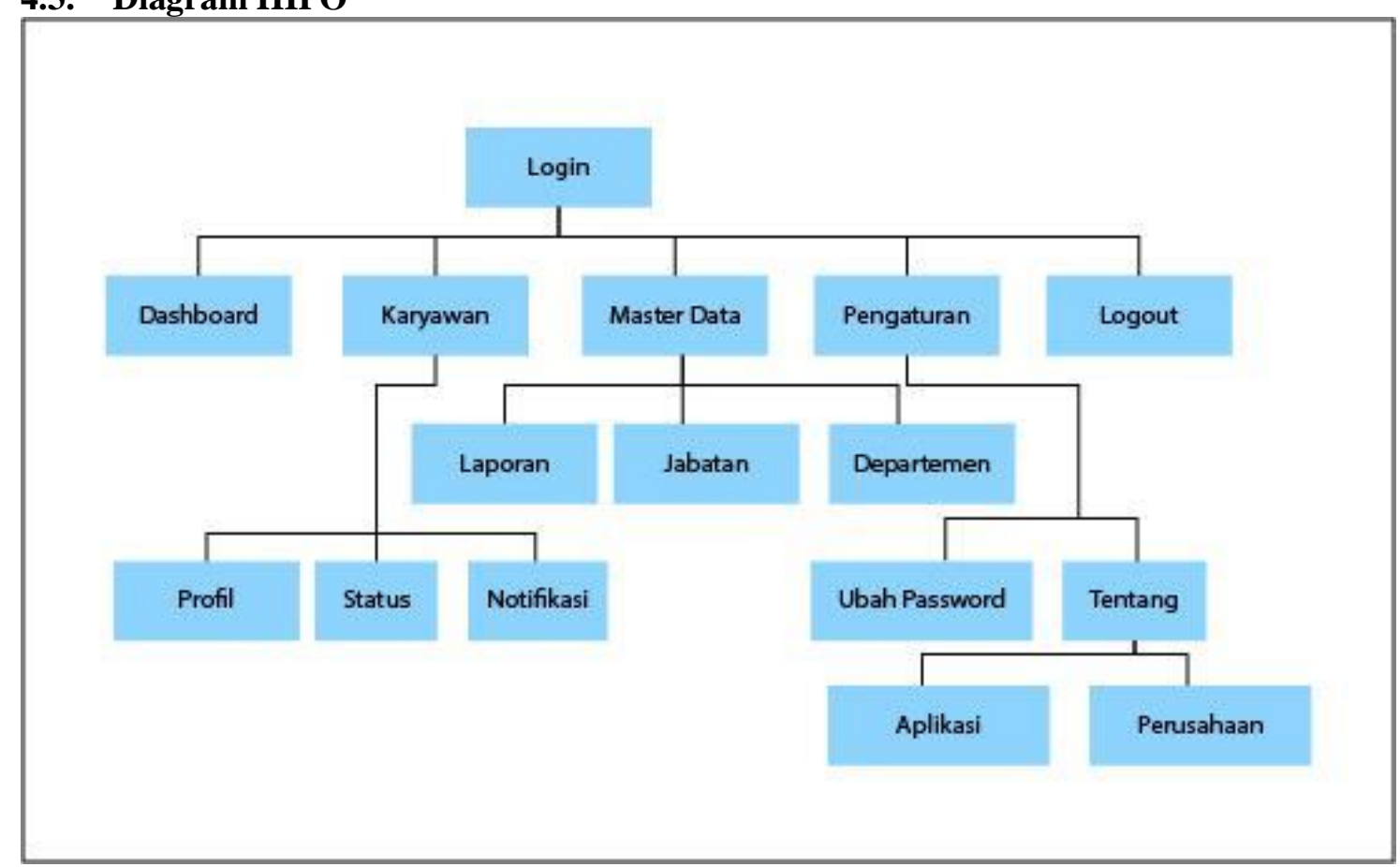

Gambar 7. HIPO

Untuk menggambarkan struktur menu dari sistem yang dirancang dapat digambarkan dengan diagram HIPO (Hierarchy Input Process Output).Untuk menyediakan suatu struktur guna memahami fungsi-fungsi dari program.Terlihat dari diagram HIPO diatas (gambar 7) terdapat 1 (satu) fungsi utama (diagram 0) dan 5 (tiga) fungsi dibawahnya, yaitu fungsi menu karyawan (diagram 1), menu master data (diagram 2) dan menu pengaturan (diagram 3). Didalam fungsi menu karyawan (diagram 1) terdapat 3 (tiga) fungsi sub menu yaitu fungsi menu profil (diagram 1.1), status (diagram 1.2) dan notifikasi (diagram 1.3).Didalam fungsi menu master data (diagram 2) terdapat 3 (tiga) fungsi fungsi sub menu yaitu fungsi menu laporan (diagram 2.1), menu jabatan (diagram 2.2) dan menu departemen (diagram 2.4).Di Dalam fungsi pengaturan (diagram 3) terdapat 2 (dua) fungsi sub menu yaitu fungsi ubah password (diagram 4.1), dan tentang aplikasi dan perusahaan (diagram 3.4).

\subsection{Rancangan Tampilan}




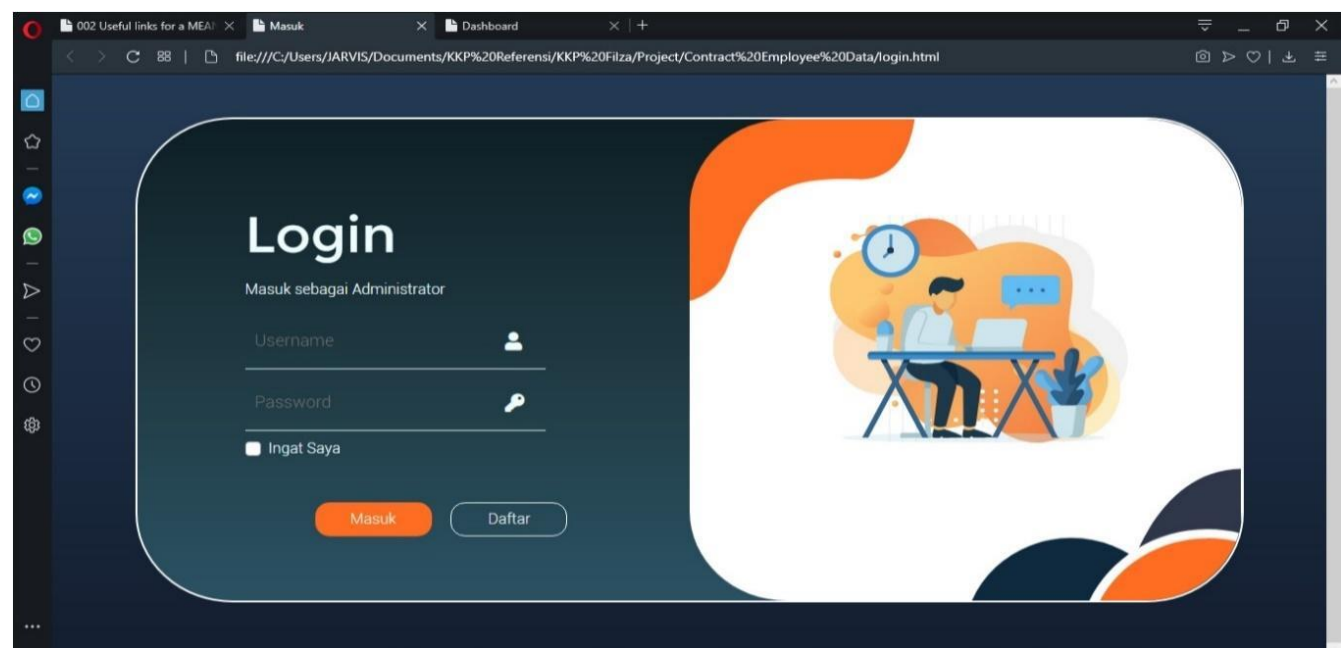

Gambar 8 Rancangan Layar Login

Terlihat pada tampilan layar diatas (gambar 8) merupakan tampilan layar login untuk masuk ke halaman Dashboard.Jika akun belum pernah dibuat sebelumnya maka bisa dengan melakukan registrasi dengan klik daftar.

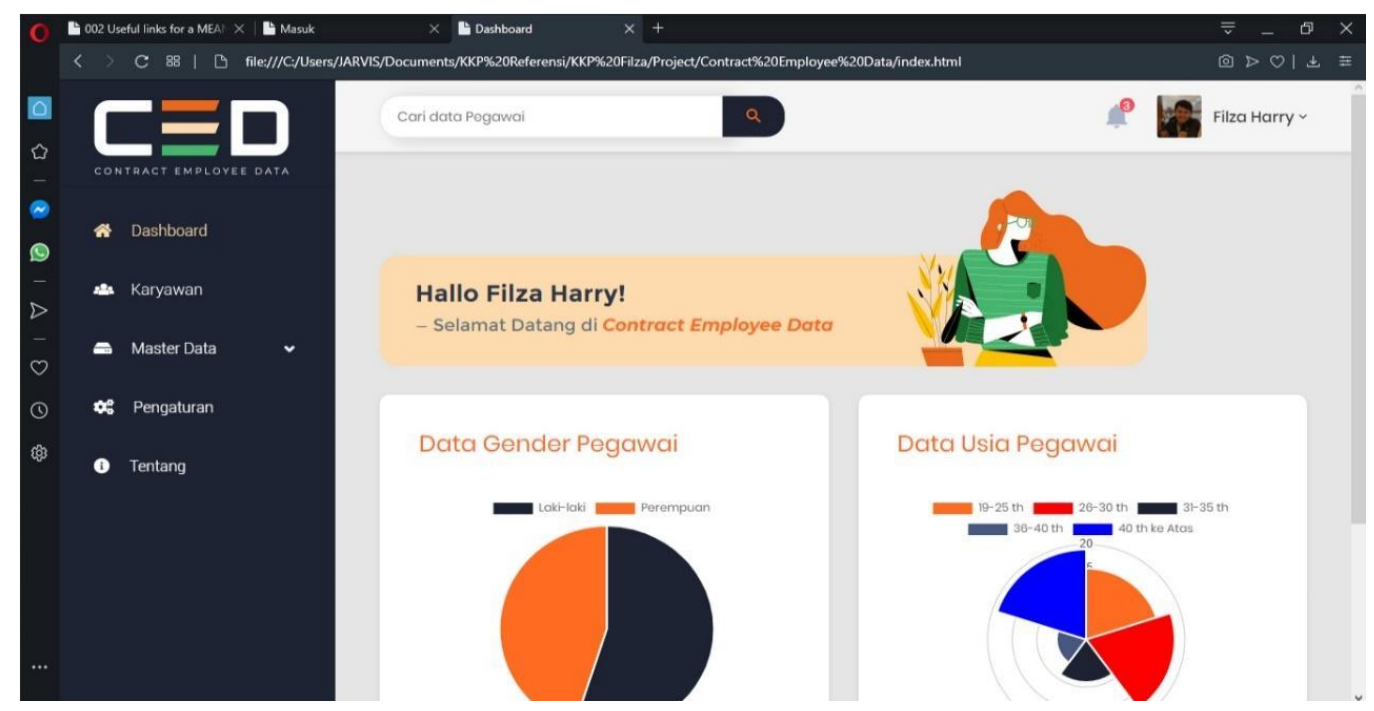

Gambar 9 Rancangan Layar Dashboard

Terlihat pada tampilan layar diatas (gambar 9) merupakan tampilan layar Dashboard yang terdiri dari Karyawan, Master Data yang dimana memiliki sub menu berupa Chart, Departemen dan Jabatan. Dibawah Master Data terdapat pengaturan dan tentang. 
ISSN: 2461-1409

Online ISSN: 2655-5298

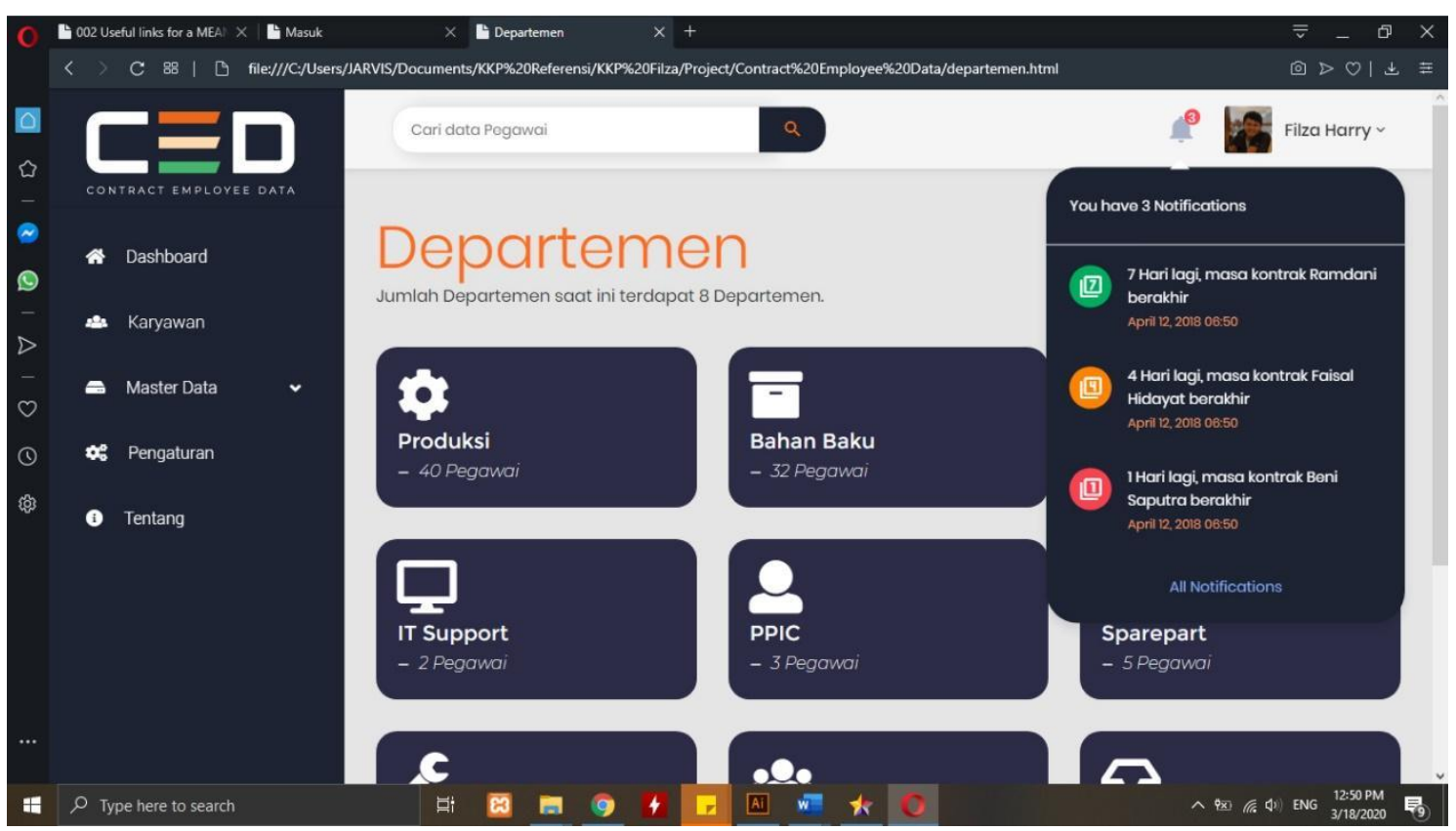

Gambar 10 Rancangan Layar Tentang dan Notifikasi

Terlihat pada tampilan layar diatas (gambar 10) merupakan tampilan layer sub menu Departemen dari menu Master Data dan di bilah samping kanan terdapat notifikasi karyawan.

\section{KESIMPULAN}

Berdasarkan hasil analisis dari rumusan masalah yang telah dilakukan, dapat disimpulkan bahwa sistem pengelolaan kontrak kerja karyawan di perusahaan outsourcing yang berjalan saat ini masih menggunakan aplikasi manual dimana dalam pengelolaan datanya memakan waktu yang lama sehingga berdampak pada lamanya penyajian laporan serta adanya beberapa kesalahan yang menyebabkan ketidak akuratan. Tingginya tingkat manualisasi dalam sistem ini akan berakibat pada kesalahan pendataan dan pengelolaan karyawan yang berpengaruh terhadap durasi kontrak serta kesepakatan antara perusahaan dengan karyawan. Untuk mengatasi semua ini, diperlukan sistem yang dapat menghasilkan laporan sistem kontrak kerja karyawan yang cepat dan akurat, sehingga tidak ada lagi keterlambatan atau kesalahan dalam penginputan data pelamar, calon karyawan maupun karyawan.Hal ini dapat dicapai dengan menggunakan beberapa metode penyelesaian seperti menggunakan UML untuk menggambarkan rancangan sistem, MySQL untuk pengolahan basis data dan JavaScript dan Node JS sebagai bahasa pemrograman dan platform perangkat lunak.

\section{DAFTAR PUSTAKA}

[1] Junaidi, Junaidi, Siti Euis Iyana Nurlia, and Fira Arbaimaniar Nurul. "Model Sistem Pengolahan Data Pengaduan Karyawan untuk Mengukur Kepuasan Pelayanan dalam Meningkatkan Kinerja Perusahaan."Journal Cerita 6.1: 63-73.

[2] Supriati, Ruli, Junaidi Junaidi, and John Hendri. "Implementation of Outsourcing Employee Sales System For Verification and Acceleration Salary Transparency." Creative Communication and Innovative Technology Journal 13.1: 76-87.

[3] Cholisoh, Novi, Sendy Zul Friandi, and Grees Wiliam. "Faktor Pengaruh Lingkungan Kerja dan Disiplin Kerja terhadap Kontribusi Kinerja Karyawan pada PT. 
Gapura Angkasa Bandara Soekarno Hatta."Cyberpreneurship Innovative and Creative Exact and Social Science 5.1: 44-63.

[4] Junaidi, Junaidi, Al Husain, and Jumaria Manda. "Rancang Bangun Sistem Informasi Simpan Pinjam sebagai Monitoring Unit Kerja untuk Mengukur Kinerja Angsuran Pembayaran."Innovative Creative and Information Technology 5.2: 213-224.

[5] M. Subekti, Warnars Junaidi, H.L.H.S., Y. Heryadi, "The 3 steps of best data warehouse model design with leaning implementation for sales transaction in franchise restaurant", Cybernetics and Computational Intelligence (CyberneticsCom) 2017 IEEE International Conference on, 20-22 Nov 2017.

[6] Cholisoh, Novi, Henderi Henderi, and Siti Khodijah. "Rancang Bangun Sistem Administrasi Perizinan Kursus untuk Meningkatkan Pelayanan Masyarakat pada Pusat Pemerintahan."Journal Cerita 5.2: 189-201.

[7] Junaidi, Junaidi, Sutrisno Sutrisno, and Koriatul Janah. "Model Aplikasi Purchasing System Untuk Monitoring Stok Dalam Mengurangi Tingkat Kerugian."Journal Sensi 5.1 (2019): 86-98.

[8] Damanik, Sehat, 2006, Outsourcing \& Perjanjian Kerja menurut UU. No.13 Tahun 2003 tentang Ketenagakerjaan. Bandung DSS Publishing

[9] Sudarto, Ferry, Novi Cholisoh, and Cheetah Savana Putri. "Sistem Informasi Pengambilan Kartu Ujian Mahasiswa Plus (Kum+) Berbasis Web." E-JURNAL JUSITI: Jurnal Sistem Informasi dan Teknologi Informasi 7.2 (2018): 153-162.

[10] J. Junaidi, A. Julianto, N. Anwar, S. Safrizal, H.L.H.S. Warnars, K. Hashimoto, "Perfecting a Video Game with Game Metrics", Telkomnika, vol. 16, no. 3, pp. 13241331, June 2018

[11] Zainuddin, A., Junaidi, J., \& Putra, R. D. (2017). Design of E-Commerce Payment System at Tokopedia Online Shopping Site. Aptisi Transactions On Management, 1(2), 143-155.

[12] Rahul Surendra Mishra, "Progressive WEB APP : Review", International Research Journal Of Engineering and Technology (IRJET), Vol.3, Issue 6, 2016.

[13] Sunarya, Lusyani, Ageng Setiani Rafika, and Novi Cholisoh. "Pengaruh Ilearning Dan Profesionalisme Dosen Terhadap Kinerja Jurusan Teknik Informatika Stmik Raharja Tangerang." 